\title{
Assessment of Appropriate Reference Genes for Quantitative Real-Time Polymerase Chain Reaction Normalisation in Magnolia sieboldii K. Koch across Various Experimental Conditions
}

\author{
Shixin Guan ${ }^{1}$, Shi Qiu², Mei Mei ${ }^{1}$, Xin $\mathrm{Hao}^{2}$, Xiaolin Zhang ${ }^{2 *}$, Xiujun $\mathrm{Lu}^{2,3 * *}$ \\ ${ }^{1}$ College of Horticulture, Shenyang Agricultural University, Shenyang 110866, Liaoning, China \\ ${ }^{2}$ College of Forestry, Shenyang Agricultural University, Shenyang 110866, Liaoning, China \\ ${ }^{3}$ Key Laboratory of Forest Tree Genetics, Breeding and Cultivation of Liaoning Province, China
}

Received: 25 August 2021

Accepted: 31 October 2021

\begin{abstract}
Magnolia sieboldii K. Koch is a famous ornamental plant. The deep dormancy of the seeds makes breeding difficult and prevents cultivation for economic purposes. Gene expression profiles of germination-related genes can provide clues for understanding the molecular mechanism of dormancy breaking. The accuracy of results acquired through quantitative real-time polymerase chain reaction (RT-qPCR), which was developed for investigating the gene expression profiles, is determined by the suitability of the selected reference gene. Nevertheless, appropriate RT-qPCR reference genes have not been determined in $M$. sieboldii. In the present study, seven potential reference genes in diverse M. sieboldii sample subgroups of different organ tissues, seed developmental stages, and seed subjected to imbibition and stratification treatments were checked through RT-qPCR. The gene expression stability was assessed and analysed through three statistical algorithms, namely, geNorm, NormFinder, and BestKeeper. Cyclophilin (CYC) and ubiquitin-conjugating enzyme (UCE) were identified as the best reference genes for diverse organs. $C Y C$ and $U C E$ were evaluated as suitable reference genes in seeds in diverse periods of development. Copper/zinc superoxide dismutase ( $\mathrm{Cu} / \mathrm{Zn}$-SOD) and manganese superoxide dismutase ( $M n-S O D)$ served as optimal reference genes during seed imbibition treatment, whereas Cu/Zn-SOD and $30 S$ ribosomal protein S13 (RPS13) were optimal during seed stratification treatment. In M. sieboldii, $C u / Z n-S O D$ was recommended for RT-qPCR normalisation, whereas $D B P$ was inappropriate for gene expression analysis. The expression pattern of DELAY OF GERMINATION1 (DOG1) was analysed for validating reference gene creditability better. The present study provides
\end{abstract}

*e-mail: zhanglin_25683921@hotmail.com

**e-mail: 1xjsyau@syau.edu.cn 
a useful guideline for appropriate reference gene selection for RT-qPCR at diverse experiment conditions for M. sieboldii.

Keywords: Magnolia sieboldii K. Koch, reference gene, RT-qPCR normalisation, gene expression, $D O G 1$ gene

\section{Introduction}

Magnolia sieboldii $\mathrm{K}$. Koch, a member of the family Magnoliaceae, is a Chinese deciduous tree that has been listed as a national endangered species due to its rarity worldwide. M. sieboldii had great economical potential because its flowers are highly ornamental and have medical applications, and the timber of the tree can be utilised for furniture-making. However, the seeds of this species are unable to germinate without the help of cold stratification or gibberellic acid treatment $[1,2]$, causing breeding difficulty due to weak natural regeneration. The molecular mechanisms underlying seed germination must be thoroughly understood for facilitating and optimising M. sieboldii growth.

The gene expression analysis is crucial in revealing the mechanisms of different biological processes at the molecular level [3]. Quantitative real-time polymerase chain reaction (RT-qPCR) is frequently used for detecting and measuring gene expression levels. This method has several advantages such as accuracy, specificity, sensitivity, reproducibility, and high throughput capability $[4,5]$. Many factors such as the quantity and quality of mRNA, efficiency of cDNA preparation and PCR, heterogeneiy of organ tissues and developmental stages, sample genotypes, and biotic and abiotic stress can greatly affect the RT-qPCR accuracy [6-8]. Currently, gene expression normalisation based on reference genes can minimise such factors $[9,10]$. Nevertheless, using unsuitable reference genes may result in misinterpreted data, eventually resulting in inaccurate, even erroneous results [11, 12]. Therefore, appropriate reference genes are vital for the RT-qPCR normalisation analysis.

An ideal reference gene must exhibit steady expression between all sample tissues and across various experimental conditions. Reference genes such as actin (ACT), tubulin (TUB), ubiquitin (UBQ), $18 S$ ribosomal RNA (18S rRNA), and glyceraldehyde-3-phosphate dehydrogenase $(G A P D H)$ are often selected for the normalisation of target gene expression levels without assessment of the expression stability due to their essential roles in primary metabolism, maintenance of cell structure, and basic cellular processes [13]. These selected reference genes are considered to display the properties of ideal reference genes. Nonetheless, such gene transcript levels have been found to alter at different development periods [14-16], tissues [17, 18], cultivars $[19,20]$ and treatments $[21,22]$. If the reference gene was variant for RT-qPCR normalisation, it will resulted in inaccurate result $[11,23]$. Furthermore, the optimal reference gene number should be identified because some gene expression analyses demand two or more reference genes $[24,25,26]$. Therefore, reference genes must be assessed in each experimental system prior to gene expression studies.

The usable algorithms for identifying the appropriate reference genes for subsequent RT-qPCR are geNorm, NormFinder and BestKeeper [24, 27, 28]. Optimal reference gene validations have been reported for several plants such as oil palm [29], Caragana microphylla [30], Jatropha curcas [17], longan [31], Nitraria tangutorum [32], Petunia hybrida [33], apple [34], Carex rigescens [35], pigeonpea [22], Lilium spp. [36], buffalo grass [21], Sanionia uncinata [37], rice [38], Caragana korshinskii [39], strawberry [16], Betula platyphylla [40], switchgrass [41, 42], Lycoris aurea [43], zucchini [44], Codonopsis pilosula [45], Oxytropis ochrocephala Bunge [46] and celery [47] with these programmes. However, to the best of our knowledge, no research has been conducted for the selection of the appropriate reference genes for $M$. sieboldii RT-qPCR analysis.

In the present work, seven potential reference genes, namely actin $(A C T)$, cyclophilin $(C Y C)$, putative $D N A$ binding protein $(D B P)$, copper/zinc superoxide dismutase $(\mathrm{Cu} / \mathrm{Zn}-\mathrm{SOD})$, manganese superoxide dismutase (Mn-SOD), $30 S$ ribosomal protein S13 (RPS13), and ubiquitin-conjugating enzyme (UCE) were selected on the basis of stably expressed evidence in previous studies $[15,16,31]$ and evaluated through RT-qPCR among diverse organs, seeds in five development periods, seeds under imbibition, and stratification treatments. Reference gene expression stability was calculated by three statistical programmes, namely geNorm, NormFinder, and BestKeeper while obtaining appropriate reference genes to normalise gene expression level. Moreover, the DELAY OF GERMINATION1 (DOG1) gene expression in the given experimental backgrounds was subjected to normalisation based on the reference genes with the highest and lowest stability for verifying appropriate reference gene validity. Our results offer valuable reference to choose appropriate reference genes across various experimental conditions in $M$. sieboldii.

\section{Materials and Methods}

\section{Plant Materials and Treatments}

Three 15-year-old M. sieboldii trees were selected from the botanical garden of Shenyang Agricultural 
University $\left(41^{\circ} 82^{\prime} \mathrm{N}, \quad 123^{\circ} 56^{\prime} \mathrm{E}\right)$ for analysing the potential reference gene expression stability, and each tree was utilised as a biological replicate. The root, stem, leaf, petiole, and flower were collected in the flowering period of $M$. sieboldii tree. The seeds were also harvested at $0,30,60,90$, and 120 days after pollination (DAP). Mature M. sieboldii seeds (120 DAP) were collected and divided into two parts; one part was utilised for imbibition, and the other part was prepared for stratification. Full seeds were chosen, and seed testas were removed manually.

For imbibition treatment, the seeds were dried for one week at ambient temperature $\left(20^{\circ} \mathrm{C}-25^{\circ} \mathrm{C}\right)$ and humidity (50\%-60\%) and were soaked in $1500 \mu \mathrm{M}$ of $\mathrm{GA}_{3}$ (Solarbio, Beijing, China) solution in the culture dish at $4^{\circ} \mathrm{C}$ under dark. The seeds were harvested at diverse time points $(0,6,12,24$, and $48 \mathrm{~h})$ after the treatment. For stratification treatment, the seeds were mixed with wet sand harboring a $20 \%$ moisture content at the mass ratio of $1: 10$ and maintained at $0^{\circ} \mathrm{C}-4^{\circ} \mathrm{C}$ under dark in the non-woven bag. The seeds were collected at $0,15,30,45$, and 60 days from the onset of treatment. The obtained samples were then subjected to liquid nitrogen freezing at once, followed by storage under $-80^{\circ} \mathrm{C}$ before subsequent use.

\section{Total RNA Isolation as well as cDNA Synthesis}

The RNAprep Pure Plant Kit with gDNA Eraser (Tiangen, Beijing, China) was used for isolating the total RNA in accordance with specific protocols. Then, 1\% (w/v) agarose gel electrophoresis (AGE) was used in assessing RNA integrity. The extracted RNA content and purity were evaluated through the NanoDrop 2000 spectrophotometer (Thermo Scientific, Waltham, MA, USA). Afterwards, oligo
dT primer was utilised with the PrimeScript ${ }^{\mathrm{TM}}$ II $1^{\text {st }}$ Strand cDNA Synthesis Kit (Takara, Beijing, China) to reversely transcribe $1 \mu \mathrm{g}$ total RNA according to instruction manual. Then, nuclease-free water was used to dilute the obtained cDNA fivefold, followed by storage under $-80^{\circ} \mathrm{C}$ for RT-qPCR.

\section{Candidate Reference Gene Selection, RT-qPCR Primer Design and Verification}

On the basis of previous studies, we selected seven candidate $M$. sieboldii reference genes to compare the stability in their expression levels among different samples. Nucleotide sequences of CYC (GenBank number MN707546), DBP (GenBank number MN707548), Cu/Zn-SOD (GenBank number MN707549), $M n-S O D$ (GenBank number MN707550), RPS13 (GenBank number MN707551), UCE (GenBank number MN707552), and $A C T$ (GenBank number MN707553) were obtained from our transcriptome dataset [48] and uploaded to National Center for Biotechnology Information (NCBI). The Primer Premier 5.0 software (http:/www.premierbiosoft.com/) was used to design RT-qPCR primers (Table 1). The primer design criteria were set as follows: melting temperature $\left(\mathrm{T}_{\mathrm{m}}\right) \quad 55^{\circ} \mathrm{C}-65^{\circ} \mathrm{C}$; primer length $15-25$ nucleotides; guanine-cytosine (GC) concentration 40\%-60\%; and amplicon length 100-300 bp. Primer specificity was evaluated with AGE, sequencing and melting curve analyses.

\section{Analysis of RT-qPCR and Gene Expression Stability}

The RT-qPCR was performed in a $10-\mu \mathrm{L}$ system on the Monad Selected q225 RT-PCR system (Monad,

Table 1. Selected candidate reference genes, primers, and PCR amplification characteristics.

\begin{tabular}{|c|c|c|c|c|c|c|}
\hline Gene & $\begin{array}{l}\text { Accession } \\
\text { number }\end{array}$ & $\begin{array}{l}\text { Forward }(\mathrm{F}) \text { and reverse }(\mathrm{R}) \\
\text { primer sequence }\left(5^{\prime}-3^{\prime}\right)\end{array}$ & $\begin{array}{l}\text { Amplicon length } \\
\text { (bp) }\end{array}$ & $\begin{array}{c}\text { Product TM } \\
\left({ }^{\circ} \mathrm{C}\right)\end{array}$ & $\mathrm{R}^{2}$ & $\begin{array}{l}\mathrm{E} \\
(\%)\end{array}$ \\
\hline$A C T$ & MN707553 & $\begin{array}{l}\text { F: GCACCACTCAATCCCAAGGC } \\
\text { R: TGCGACCACTGGCATAAAGG }\end{array}$ & 121 & 81.94 & 0.999 & 98.977 \\
\hline CYC & MN707546 & $\begin{array}{l}\text { F: GACCTGGAACGAACGGCTCT } \\
\text { R: GACCGCAATCGGCAATCA }\end{array}$ & 177 & 86.79 & 0.999 & 101.914 \\
\hline$M n-S O D$ & MN707550 & $\begin{array}{l}\text { F: GTTGGGCTATTGACACTCATTTTG } \\
\text { R: GCTCCTTTAGTTACCAGCGGATC }\end{array}$ & 172 & 82.46 & 0.999 & 100.424 \\
\hline $\mathrm{Cu} / \mathrm{Zn}-\mathrm{SOD}$ & MN707549 & $\begin{array}{l}\text { F: GTGGCAAGGAGGGTGTTTGTG } \\
\text { R: CATGGAGCCCAGGTTGAAGG }\end{array}$ & 102 & 83.62 & 0.999 & 100.800 \\
\hline RPS13 & MN707551 & $\begin{array}{c}\text { F: AGTCAGCAAAGGAGGAAACCCT } \\
\text { R: CCGCCCTATGCCGTGTATG }\end{array}$ & 187 & 82.88 & 0.997 & 107.074 \\
\hline$D B P$ & MN707548 & $\begin{array}{c}\text { F: CCCAACGCACTCCGTAGCC } \\
\text { R: CCCGTCAGGGACAGTATCTCAAA }\end{array}$ & 206 & 89.29 & 0.997 & 101.341 \\
\hline$U C E$ & MN707552 & $\begin{array}{l}\text { F: AGGACCCTCCCACATCTTGC } \\
\text { R: CGGGGCTCCACTGCTCTTT }\end{array}$ & 243 & 84.69 & 0.997 & 96.068 \\
\hline$D O G 1$ & MN707547 & $\begin{array}{l}\text { F: CTTAGCGGCTCTGGCGAATC } \\
\text { R: TGCTGACGGTCCCTCCTTTT }\end{array}$ & 168 & 86.04 & 0.998 & 96.515 \\
\hline
\end{tabular}


Wuhan, China). The reaction system consisted of MonAmp ${ }^{\mathrm{TM}} \mathrm{SYBR}^{\circledR}$ Green qPCR Mix $(5 \mu \mathrm{L}$, Monad, Wuhan, China), nuclease-free water $(3 \mu \mathrm{L}), 0.5 \mu \mathrm{L}$ of each primer $(10 \mu \mathrm{M})$, and cDNA $(1 \mu \mathrm{L})$. The reaction was conducted under the following three-step cycling conditions: 3 min under $95^{\circ} \mathrm{C} ; 10 \mathrm{~s}$ under $95^{\circ} \mathrm{C}, 10 \mathrm{~s}$ under $58^{\circ} \mathrm{C}$ and $30 \mathrm{~s}$ under $72^{\circ} \mathrm{C}$ for 40 cycles in the 96-well plate (Monad, Wuhan, China). Melting curves were examined after 40 cycles under $60^{\circ} \mathrm{C}-95^{\circ} \mathrm{C}$ (increment $0.5^{\circ} \mathrm{C} / 5$ s) to verify primer specificity. The no-template control was also used to monitor the potential reagent contamination. Furthermore, the whole samples for each gene across the same experimental condition were run on the same plate to avoid any interplate differences and technical changes. Each reaction was conducted for three biological and three technical replicates. The standard curve obtained from the tenfold serial dilutions of cDNA pools $\left(10^{-0}, 10^{-1}, 10^{-2}, 10^{-3}, 10^{-4}\right)$ was used to assess the amplification efficiency (E) and correlation coefficient $\left(\mathrm{R}^{2}\right)$.

The RT-qPCR data obtained from the Monad Selected q225 manager were entered into the Excel datasheet. Gene expression stability across various experimental conditions was ranked by geNorm [24], NormFinder [27], and BestKeeper [28]. These Excelbased tools were run according to their manuals.

\section{Verification of Reference Genes}

DOG1 (DELAY OF GERMINATION1) plays a vital role during seed dormancy, seed chilling response and plant growth [49, 50]. For the important regulatory effects, MsDOG1 (GenBank number MN707547) was selected for verifying the identified reference gene creditability. Nucleotide sequence of MsDOG1 was acquired based on our transcriptome dataset [48] and uploaded to NCBI. Specific primers for MsDOG1 are shown in Table 1. Primer design, verification and RT-qPCR was conducted similar to the abovementioned methods. The reference genes with the highest stability among diverse organ tissues (CYC, UCE), seed developmental stages (CYC, UCE), seed imbibition (Cu/Zn-SOD, Mn-SOD), and seed stratification (RPS13, Cu/Zn-SOD) subsets, and those with the lowest stability among diverse organ tissues $(R P S 13, \quad D B P)$, seed developmental stages (Mn$S O D, D B P$ ), seed imbibition (RPS13, DBP), and seed stratification $(C Y C, D B P)$ subsets were selected as calibrators to evaluate the MsDOG1 expression level.

\section{Results}

\section{Evaluation of Amplification Specificity and Efficiency}

Specific primers were screened for the seven potential reference genes to carry out RT-qPCR, with the length of amplicon varying between 102 and $243 \mathrm{bp}$ (Table 1). Amplicon specificity was typically verified with the presence of a single band that exhibited the designed size on 2\% AGE (Fig. 1a). Single-peak melting curves for the seven potential reference genes exhibited the specific amplifications of all primers (Fig. 1b). In the meantime, the no-template control, where cDNA was replaced by nuclease-free water in equal volume, did not exhibit amplicons for each selected reference gene. Additionally, the sequence analysis demonstrated that the amplified sequences were aligned to the sequences used for primer design. The melting temperature of RT-qPCR products spanned from $81.94^{\circ} \mathrm{C}$ for $A C T$ to $89.29^{\circ} \mathrm{C}$ for $D B P$ (Table 1). The amplification efficiency was between $96.068 \%$ for $U C E$ and $107.074 \%$ for RPS13, and the standard curve $\mathrm{R}^{2}$ values changed between 0.997 and 0.999 (Table 1).

\section{Expression Profiles for the Potential Reference Genes}

Transcript abundances for the seven potential reference genes obtained through RT-qPCR were presented as values of cycle threshold $(\mathrm{Ct})$. All $\mathrm{Ct}$ values for these potential reference genes are tabulated in Table 2. $\mathrm{Ct}$ values for the potential reference genes varied greatly between $14.16(C Y C)$ and $33.27(D B P)$ (Fig. 2, Table 3). CYC showed the highest expression with the lowest average $\mathrm{Ct}$ value (16.50), whereas $D B P$ showed the lowest expression with the highest average $\mathrm{Ct}$ value (29.79). The transcript abundance of the $D B P$ gene exhibited the greatest variation (11.13 Ct, with the maximum and minimum $\mathrm{Ct}$ values being 33.27 and 22.14, respectively), whereas that of the UCE gene exhibited the smallest variation $(3.12 \mathrm{Ct}$, with the maximum and minimum $\mathrm{Ct}$ values being 22.39 and 19.27 , respectively).

\section{Examination of Potential Reference Gene Expression Stability}

The expression stability of the seven potential reference genes was determined among diverse experiment sets, followed by separate ranking using the three statistical algorithms (geNorm, NormFinder, and BestKeeper) (Table 4).

The reference gene expression stability can be ranked using the geNorm algorithm in accordance with the values of mean expression stability (M) from mean pairwise expression ratio [24]. Typically, the threshold $\mathrm{M}$ is $<1.5$, and potential reference genes having low $\mathrm{M}$ values exhibit stable expression [51]. For seeds under imbibition treatment, $\mathrm{Cu} / \mathrm{Zn}-\mathrm{SOD}$ and $\mathrm{Mn}-\mathrm{SOD}$ genes exhibited the highest stability, and the $M$ values were both 0.13 . CYC and UCE genes exhibited the highest suitability for diverse organ tissues as well as seeds at different developmental stages, and the $M$ values were 0.51 and 0.26 , respectively. For seeds during stratification treatment, the gene pairs with the highest 
expression stability were RPS13 and $C u / Z n-S O D$ with an $\mathrm{M}$ value of 0.23 . After pooling each sample into the geNorm analysis, $U C E$ and $C u / Z n-S O D(\mathrm{M}=0.50)$ were identified as the genes with the highest expression stability, whereas $D B P(\mathrm{M}=1.48)$ and $M n-S O D$ $(\mathrm{M}=1.00)$ were identified as genes with the lowest expression stability.
The geNorm algorithm may be further utilised for identifying the best reference gene number for accurate gene expression normalization through computing the pairwise variation $\left(\mathrm{V}_{\mathrm{n}} / \mathrm{V}_{\mathrm{n}+1}\right)$. The $\mathrm{V}_{\mathrm{n}} / \mathrm{V}_{\mathrm{n}+1}$ value of $<0.15$ reveals that the best reference gene number identical to the $n$ value is adequate [24]. In the present study, the $\mathrm{V}_{2} / \mathrm{V}_{3}$ values for seeds under imbibition

a)

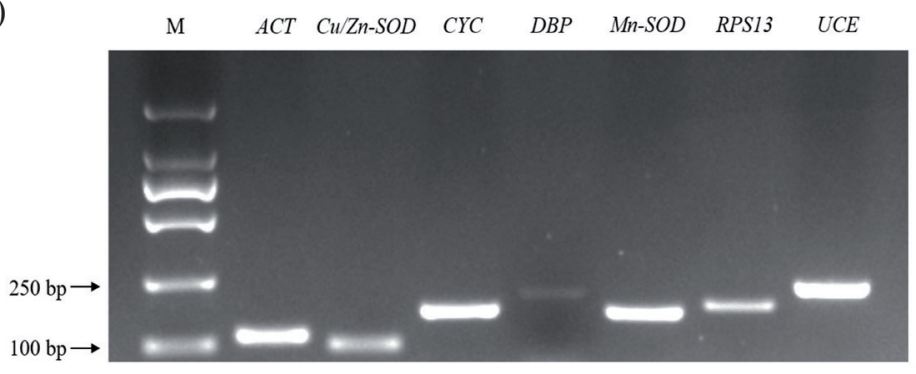

b)

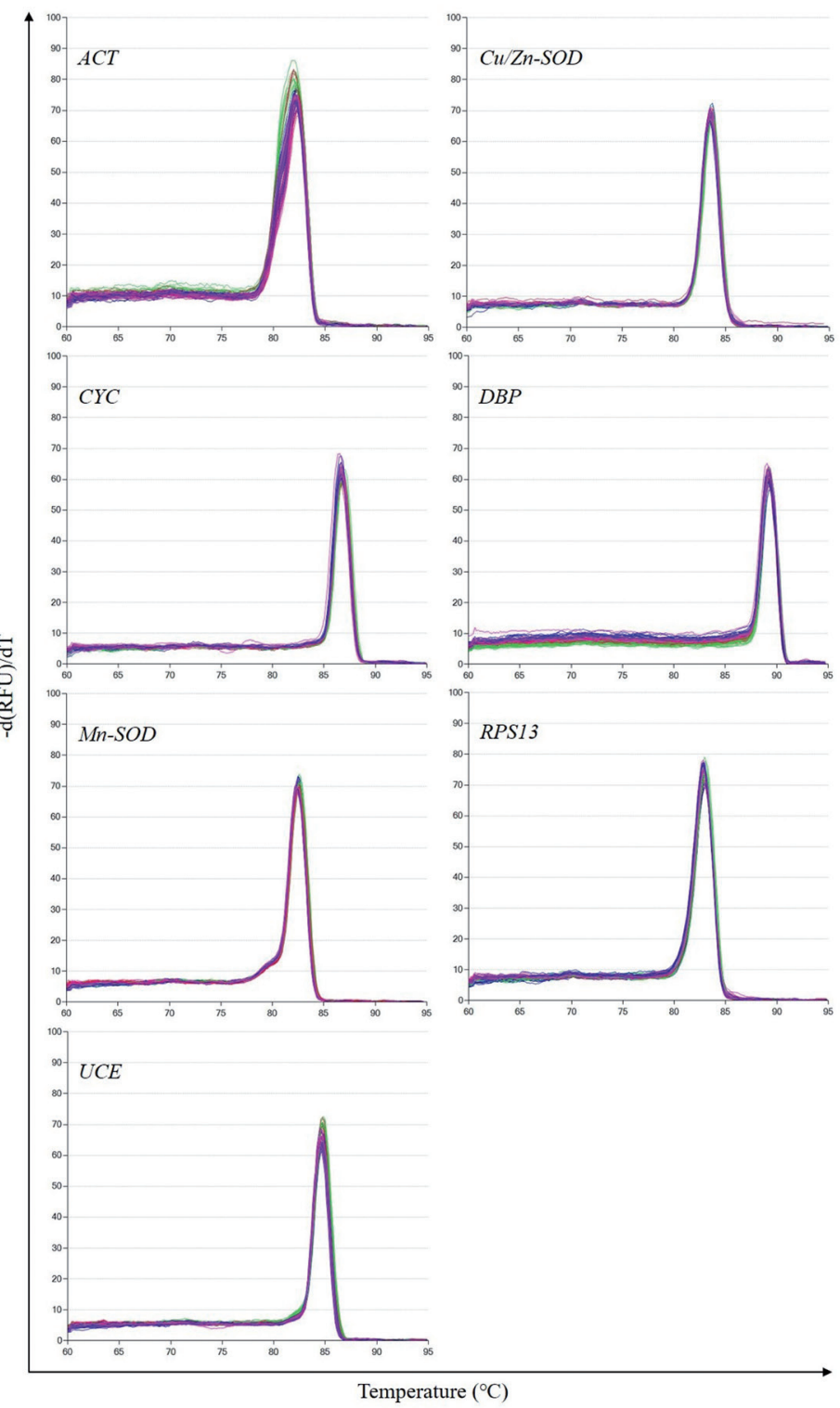

Fig. 1. Primer amplification specificity for RT-qPCR analysis. a) PCR amplifications of seven candidate reference genes on $2 \%$ agarose gel. A single band with the expected size represents the amplicon specificity. b) Melting curves for the seven potential reference genes in all samples with three biological replicates. A single peak represents the primer specificity. 
Table 2. Ct values of all samples in $M$. sieboldii.

\begin{tabular}{|c|c|c|c|c|c|c|c|c|}
\hline & & $A C T$ & $C Y C$ & $D B P$ & $M n-S O D$ & $\mathrm{Cu} / \mathrm{Zn}-\mathrm{SOD}$ & RPS13 & $U C E$ \\
\hline \multirow{15}{*}{$\begin{array}{c}\text { Different } \\
\text { developmental } \\
\text { stages }\end{array}$} & \multirow{3}{*}{0 DAP } & 18.776 & 14.131 & 24.806 & 19.604 & 16.392 & 21.796 & 19.196 \\
\hline & & 18.826 & 14.234 & 24.955 & 19.695 & 16.764 & 21.913 & 19.262 \\
\hline & & 18.974 & 14.125 & 25.018 & 19.730 & 16.767 & 21.913 & 19.355 \\
\hline & \multirow{3}{*}{30 DAP } & 19.362 & 15.597 & 30.640 & 17.225 & 17.836 & 21.582 & 20.047 \\
\hline & & 19.423 & 15.679 & 30.579 & 17.240 & 17.833 & 21.561 & 20.173 \\
\hline & & 19.374 & 15.652 & 30.487 & 17.234 & 17.968 & 21.586 & 20.113 \\
\hline & \multirow{3}{*}{60 DAP } & 19.727 & 15.762 & 29.256 & 17.588 & 17.813 & 22.195 & 20.718 \\
\hline & & 19.777 & 15.623 & 29.531 & 17.686 & 17.836 & 22.223 & 20.587 \\
\hline & & 19.636 & 15.660 & 29.271 & 17.681 & 17.878 & 22.212 & 20.694 \\
\hline & \multirow{3}{*}{90 DAP } & 19.987 & 15.621 & 29.546 & 18.327 & 18.410 & 22.560 & 20.597 \\
\hline & & 20.074 & 15.598 & 29.425 & 18.335 & 18.472 & 22.446 & 20.613 \\
\hline & & 20.180 & 15.719 & 29.781 & 18.407 & 18.538 & 22.476 & 20.659 \\
\hline & \multirow{3}{*}{120 DAP } & 20.770 & 15.715 & 29.690 & 18.999 & 18.021 & 22.785 & 20.378 \\
\hline & & 20.673 & 15.695 & 29.600 & 19.057 & 18.040 & 22.830 & 20.287 \\
\hline & & 20.709 & 15.699 & 29.982 & 19.078 & 18.052 & 22.821 & 20.543 \\
\hline \multirow{15}{*}{$\begin{array}{l}\text { Different organ } \\
\text { tissues }\end{array}$} & \multirow{3}{*}{ Root } & 20.158 & 16.560 & 22.031 & 22.719 & 18.308 & 24.249 & 21.555 \\
\hline & & 20.190 & 16.598 & 22.142 & 22.735 & 18.349 & 24.358 & 21.857 \\
\hline & & 20.222 & 16.623 & 22.238 & 22.767 & 18.352 & 24.364 & 21.570 \\
\hline & \multirow{3}{*}{ Stem } & 19.404 & 15.378 & 27.778 & 19.287 & 18.164 & 21.900 & 20.434 \\
\hline & & 19.429 & 15.433 & 27.854 & 19.259 & 18.156 & 21.951 & 20.455 \\
\hline & & 19.128 & 15.432 & 27.836 & 19.239 & 18.156 & 21.907 & 20.418 \\
\hline & \multirow{3}{*}{ Leaf } & 21.527 & 16.223 & 26.864 & 22.167 & 19.994 & 20.619 & 21.988 \\
\hline & & 21.733 & 16.247 & 27.052 & 22.204 & 20.056 & 20.688 & 21.975 \\
\hline & & 21.675 & 16.310 & 27.014 & 22.218 & 20.075 & 20.714 & 21.985 \\
\hline & \multirow{3}{*}{ Petiole } & 20.584 & 17.211 & 28.548 & 23.391 & 19.648 & 23.813 & 22.074 \\
\hline & & 20.642 & 17.258 & 28.767 & 23.594 & 19.667 & 23.964 & 22.159 \\
\hline & & 20.695 & 17.339 & 28.902 & 23.686 & 19.690 & 24.036 & 22.073 \\
\hline & \multirow{3}{*}{ Flower } & 18.712 & 16.083 & 28.989 & 19.896 & 18.727 & 22.265 & 20.234 \\
\hline & & 18.657 & 16.117 & 29.276 & 20.205 & 18.809 & 22.266 & 20.228 \\
\hline & & 18.788 & 15.815 & 28.945 & 20.182 & 18.863 & 22.299 & 20.494 \\
\hline \multirow{15}{*}{$\begin{array}{l}\text { Imbibition } \\
\text { (GA3) }\end{array}$} & \multirow{3}{*}{$0 \mathrm{~h}$} & 22.260 & 17.910 & 33.085 & 20.578 & 20.122 & 23.855 & 22.323 \\
\hline & & 22.293 & 18.030 & 33.214 & 20.625 & 20.184 & 23.924 & 22.419 \\
\hline & & 22.306 & 18.067 & 33.496 & 20.644 & 20.171 & 23.940 & 22.277 \\
\hline & \multirow{3}{*}{$6 \mathrm{~h}$} & 22.402 & 17.787 & 32.583 & 20.091 & 19.757 & 24.490 & 22.347 \\
\hline & & 22.404 & 17.897 & 32.747 & 20.198 & 19.956 & 24.502 & 22.412 \\
\hline & & 22.377 & 17.718 & 32.332 & 20.066 & 19.791 & 24.489 & 22.396 \\
\hline & \multirow{3}{*}{$12 \mathrm{~h}$} & 21.702 & 16.856 & 32.805 & 19.706 & 19.328 & 23.238 & 21.696 \\
\hline & & 21.945 & 16.894 & 32.421 & 19.688 & 19.338 & 23.415 & 21.560 \\
\hline & & 21.856 & 16.657 & 32.392 & 19.736 & 19.266 & 23.409 & 21.682 \\
\hline & \multirow{3}{*}{$24 \mathrm{~h}$} & 21.326 & 16.605 & 31.157 & 18.982 & 18.662 & 23.290 & 21.017 \\
\hline & & 21.489 & 16.667 & 31.204 & 19.069 & 18.785 & 23.230 & 21.154 \\
\hline & & 21.565 & 16.700 & 31.102 & 19.053 & 18.769 & 23.307 & 21.053 \\
\hline & \multirow{3}{*}{$48 \mathrm{~h}$} & 21.903 & 16.553 & 32.199 & 19.539 & 19.400 & 22.904 & 20.986 \\
\hline & & 21.759 & 16.650 & 32.441 & 19.631 & 19.614 & 22.893 & 21.043 \\
\hline & & 21.740 & 16.537 & 32.453 & 19.666 & 19.475 & 22.876 & 20.969 \\
\hline
\end{tabular}


Table 2. Continued.

\begin{tabular}{|c|c|c|c|c|c|c|c|c|}
\hline \multirow{15}{*}{ Stratification } & \multirow{3}{*}{$0 \mathrm{~d}$} & 21.417 & 16.581 & 30.928 & 19.420 & 19.125 & 22.973 & 21.184 \\
\hline & & 21.417 & 16.580 & 31.268 & 19.484 & 19.198 & 23.093 & 21.206 \\
\hline & & 21.299 & 16.610 & 31.347 & 19.479 & 19.262 & 23.208 & 21.122 \\
\hline & \multirow{3}{*}{$15 \mathrm{~d}$} & 21.090 & 17.209 & 29.585 & 18.630 & 18.938 & 22.611 & 20.258 \\
\hline & & 21.182 & 17.489 & 29.952 & 18.993 & 19.136 & 22.742 & 20.384 \\
\hline & & 21.101 & 17.416 & 29.734 & 19.016 & 19.188 & 22.746 & 20.291 \\
\hline & \multirow{3}{*}{$30 \mathrm{~d}$} & 20.897 & 17.541 & 31.629 & 19.506 & 19.134 & 22.438 & 20.645 \\
\hline & & 20.956 & 17.240 & 31.975 & 19.225 & 19.126 & 22.325 & 20.393 \\
\hline & & 20.874 & 17.139 & 32.045 & 19.443 & 19.141 & 22.414 & 20.613 \\
\hline & \multirow{3}{*}{$45 \mathrm{~d}$} & 21.331 & 16.938 & 31.138 & 19.071 & 18.840 & 22.995 & 21.146 \\
\hline & & 21.365 & 16.943 & 31.284 & 19.073 & 18.902 & 23.067 & 21.144 \\
\hline & & 21.451 & 16.973 & 31.422 & 19.112 & 18.992 & 23.083 & 21.222 \\
\hline & \multirow{3}{*}{$60 \mathrm{~d}$} & 20.336 & 17.518 & 30.803 & 20.001 & 18.765 & 22.291 & 20.668 \\
\hline & & 20.383 & 17.742 & 30.780 & 20.115 & 18.952 & 22.543 & 20.926 \\
\hline & & 20.354 & 17.630 & 30.800 & 20.166 & 18.868 & 22.471 & 20.981 \\
\hline
\end{tabular}

$\mathrm{Ct}$ value of each biological replicate is the mean of three technical replicates.

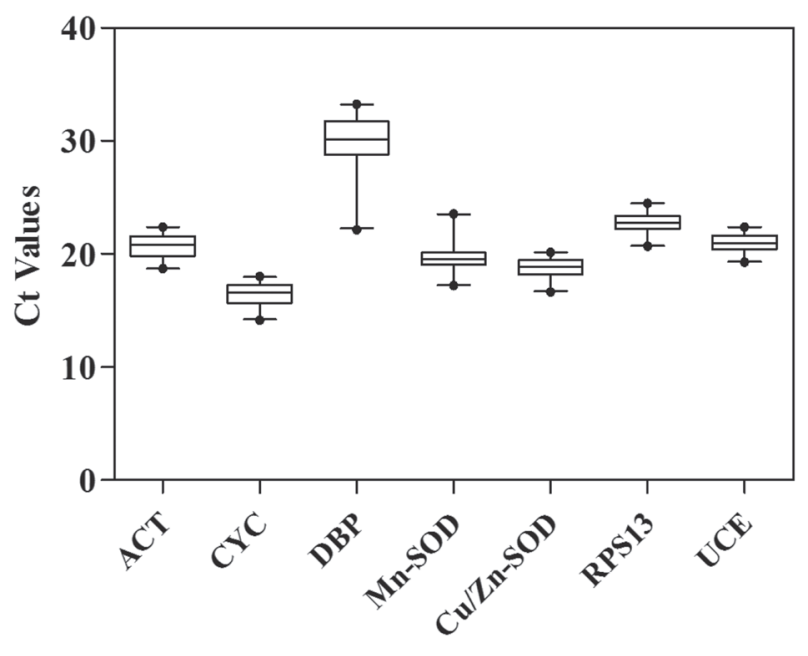

Fig. 2. Ct values for the seven potential reference genes across all M. Sieboldii samples. Boxes depict the $25^{\text {th }}$ and $75^{\text {th }}$ percentiles. Lines across the boxes depict the median values. Whiskers indicate the maximum and minimum values. Black dots indicate outliers. The higher boxes and whiskers indicate the larger variations. treatment, during stratification treatment, and at different developmental stages were lower than 0.15 $(0.084,0.112$, and 0.080 , respectively), suggesting the necessity of two reference genes to normalise the target genes. However, all $\mathrm{V}_{\mathrm{n}} / \mathrm{V}_{\mathrm{n}+1}$ values among diverse organs and total samples were higher than 0.15 (Fig. 3). Hence, the threshold of 0.15 was slightly rigorous in these experimental conditions. Numerous studies have indicated that the application of a threshold of 0.15 is merely a suggestion, and whether it is practically applied is determined by the data [52-54]. In general, a reliable normalisation could also be performed with one reference gene in most of experiments $[16,31,36]$. In view of this, one reference gene was adopted for each of the experimental conditions.

NormFinder algorithm can be used to rank the gene expression stability through the calculation of the mean pairwise variation of one reference gene with the rest of genes [27]. Genes that possess the minimum expression stability value are featured to be the tested reference genes with the highest stability [27]. The stability ranking for the seven genes obtained through NormFinder analysis was relatively identical to the data array of geNorm. CYC and UCE were

Table 3. Ct value characteristics of the seven potential reference genes in M. Sieboldii.

\begin{tabular}{|c|c|c|c|c|c|c|c|}
\hline & $A C T$ & $C Y C$ & $D B P$ & Mn-SOD & Cu/Zn-SOD & RPS13 & UCE \\
\hline Minimum & 18.72 & 14.16 & 22.14 & 17.23 & 16.64 & 20.67 & 19.27 \\
\hline Maximum & 22.39 & 18.00 & 33.27 & 23.56 & 20.16 & 24.49 & 22.39 \\
\hline Mean & 20.71 & 16.50 & 29.79 & 19.79 & 18.83 & 22.78 & 21.00 \\
\hline Median & 20.81 & 16.59 & 30.16 & 19.54 & 18.89 & 22.76 & 20.93 \\
\hline
\end{tabular}




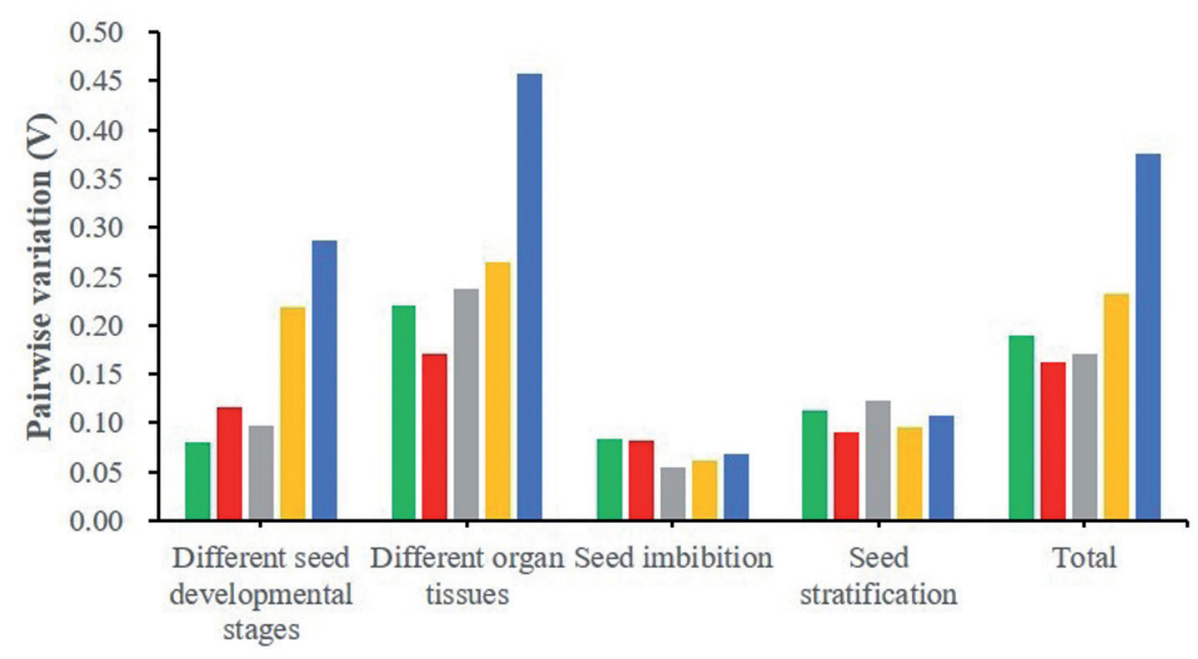

Fig. 3. Pairwise variation (V) for the seven potential reference genes. The geNorm algorithm was utilised to analyse the pairwise variation $\left(\mathrm{V}_{\mathrm{n}} / \mathrm{V}_{\mathrm{n}+1}\right)$ of normalisation factors $\left(\mathrm{NF}_{\mathrm{n}}\right.$ and $\left.\mathrm{NF}_{\mathrm{n}+1}\right)$. The best reference gene number was determined to accurately normalise gene expression according to $\mathrm{V}<0.15$.

Table 4 . The seven potential reference gene expression stability determined using the geNorm, NormFinder, and BestKeeper algorithms.

\begin{tabular}{|c|c|c|c|c|c|c|c|c|}
\hline \multirow{2}{*}{ Group } & \multirow{2}{*}{ Rank } & \multicolumn{2}{|c|}{ geNorm } & \multicolumn{2}{|c|}{ NormFinder } & \multicolumn{3}{|c|}{ BestKeeper } \\
\hline & & Gene & Stability & Gene & Stability & Gene & $\mathrm{SD}[ \pm \mathrm{CP}]$ & $\mathrm{CV}[\% \mathrm{CP}]$ \\
\hline \multirow{7}{*}{$\begin{array}{c}\text { Different seed } \\
\text { developmental } \\
\text { stages }\end{array}$} & 1 & $C Y C$ & 0.26 & $C Y C$ & 0.090 & RPS13 & 0.37 & 1.69 \\
\hline & 2 & $U C E$ & 0.26 & $U C E$ & 0.090 & $U C E$ & 0.42 & 2.07 \\
\hline & 3 & $\mathrm{Cu} / \mathrm{Zn}-\mathrm{SOD}$ & 0.27 & $\mathrm{Cu} / \mathrm{Zn}-\mathrm{SOD}$ & 0.091 & $\mathrm{Cu} / \mathrm{Zn}-\mathrm{SOD}$ & 0.45 & 2.55 \\
\hline & 4 & $A C T$ & 0.38 & $A C T$ & 0.125 & $\mathrm{CYC}$ & 0.48 & 3.13 \\
\hline & 5 & RPS13 & 0.44 & RPS13 & 0.244 & $A C T$ & 0.52 & 2.62 \\
\hline & 6 & $M n-S O D$ & 0.73 & $M n-S O D$ & 1.082 & $M n-S O D$ & 0.77 & 4.21 \\
\hline & 7 & $D B P$ & 1.10 & $D B P$ & 1.383 & $D B P$ & 1.56 & 5.43 \\
\hline \multirow{7}{*}{$\begin{array}{l}\text { Different organ } \\
\text { tissues }\end{array}$} & 1 & $C Y C$ & 0.51 & $C Y C$ & 0.176 & CYC & 0.50 & 3.06 \\
\hline & 2 & $U C E$ & 0.51 & $U C E$ & 0.176 & $\mathrm{Cu} / \mathrm{Zn}-\mathrm{SOD}$ & 0.68 & 3.60 \\
\hline & 3 & $\mathrm{Cu} / \mathrm{Zn}-\mathrm{SOD}$ & 0.64 & $\mathrm{Cu} / \mathrm{Zn}-\mathrm{SOD}$ & 0.233 & $U C E$ & 0.74 & 3.47 \\
\hline & 4 & $A C T$ & 0.69 & $A C T$ & 0.569 & $A C T$ & 0.87 & 4.31 \\
\hline & 5 & $M n-S O D$ & 0.92 & $M n-S O D$ & 0.936 & RPS13 & 1.20 & 5.32 \\
\hline & 6 & RPS13 & 1.17 & RPS13 & 1.133 & $M n-S O D$ & 1.51 & 7.02 \\
\hline & 7 & $D B P$ & 1.77 & $D B P$ & 2.203 & $D B P$ & 1.92 & 7.14 \\
\hline \multirow{7}{*}{ Seed imbibition } & 1 & $\mathrm{Cu} / \mathrm{Zn}-\mathrm{SOD}$ & 0.13 & $M n-S O D$ & 0.089 & $A C T$ & 0.31 & 1.40 \\
\hline & 2 & Mn-SOD & 0.13 & $\mathrm{Cu} / \mathrm{Zn}-\mathrm{SOD}$ & 0.131 & $\mathrm{Cu} / \mathrm{Zn}-\mathrm{SOD}$ & 0.39 & 2.01 \\
\hline & 3 & $A C T$ & 0.22 & $A C T$ & 0.139 & $M n-S O D$ & 0.44 & 2.22 \\
\hline & 4 & CYC & 0.28 & $U C E$ & 0.147 & RPS13 & 0.49 & 2.09 \\
\hline & 5 & $U C E$ & 0.30 & CYC & 0.161 & $D B P$ & 0.49 & 1.52 \\
\hline & 6 & RPS13 & 0.33 & RPS13 & 0.288 & $U C E$ & 0.54 & 2.48 \\
\hline & 7 & DBP & 0.38 & $D B P$ & 0.320 & CYC & 0.59 & 3.42 \\
\hline
\end{tabular}


Table 4. Continued.

\begin{tabular}{|c|c|c|c|c|c|c|c|c|}
\hline \multirow{7}{*}{$\begin{array}{c}\text { Seed } \\
\text { stratification }\end{array}$} & 1 & $A C T$ & 0.23 & $\mathrm{Cu} / \mathrm{Zn}-\mathrm{SOD}$ & 0.102 & $\mathrm{Cu} / \mathrm{Zn}-\mathrm{SOD}$ & 0.12 & 0.64 \\
\hline & 2 & RPS13 & 0.23 & $U C E$ & 0.163 & RPS13 & 0.27 & 1.18 \\
\hline & 3 & $\mathrm{Cu} / \mathrm{Zn}-\mathrm{SOD}$ & 0.31 & RPS13 & 0.215 & $U C E$ & 0.31 & 1.47 \\
\hline & 4 & $U C E$ & 0.35 & $A C T$ & 0.315 & $A C T$ & 0.32 & 1.51 \\
\hline & 5 & $M n-S O D$ & 0.46 & $M n-S O D$ & 0.324 & $M n-S O D$ & 0.32 & 1.65 \\
\hline & 6 & $C Y C$ & 0.53 & $C Y C$ & 0.395 & $C Y C$ & 0.32 & 1.86 \\
\hline & 7 & $D B P$ & 0.61 & $D B P$ & 0.513 & $D B P$ & 0.56 & 1.82 \\
\hline \multirow{7}{*}{ Total } & 1 & $\mathrm{Cu} / \mathrm{Zn}-\mathrm{SOD}$ & 0.50 & $U C E$ & 0.157 & $U C E$ & 0.65 & 3.09 \\
\hline & 2 & $U C E$ & 0.50 & $\mathrm{Cu} / \mathrm{Zn}-\mathrm{SOD}$ & 0.173 & $\mathrm{Cu} / \mathrm{Zn}-\mathrm{SOD}$ & 0.66 & 3.49 \\
\hline & 3 & CYC & 0.58 & CYC & 0.191 & RPS13 & 0.73 & 3.20 \\
\hline & 4 & $A C T$ & 0.65 & $A C T$ & 0.234 & CYC & 0.75 & 4.55 \\
\hline & 5 & RPS13 & 0.77 & RPS13 & 0.533 & $A C T$ & 0.91 & 4.41 \\
\hline & 6 & $M n-S O D$ & 1.00 & $M n-S O D$ & 1.161 & $M n-S O D$ & 1.09 & 5.50 \\
\hline & 7 & $D B P$ & 1.48 & $D B P$ & 1.808 & $D B P$ & 1.97 & 6.62 \\
\hline
\end{tabular}

a)

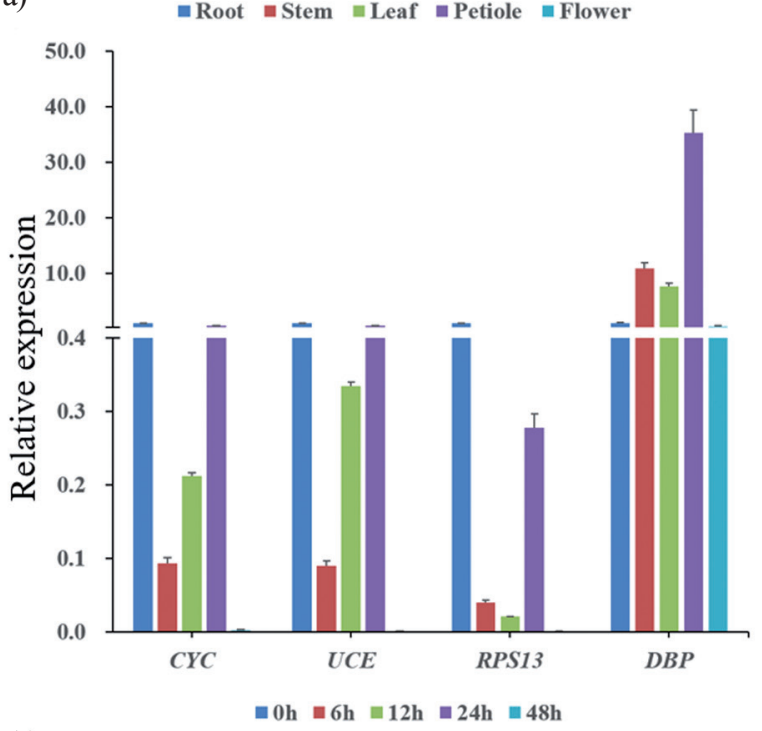

c)

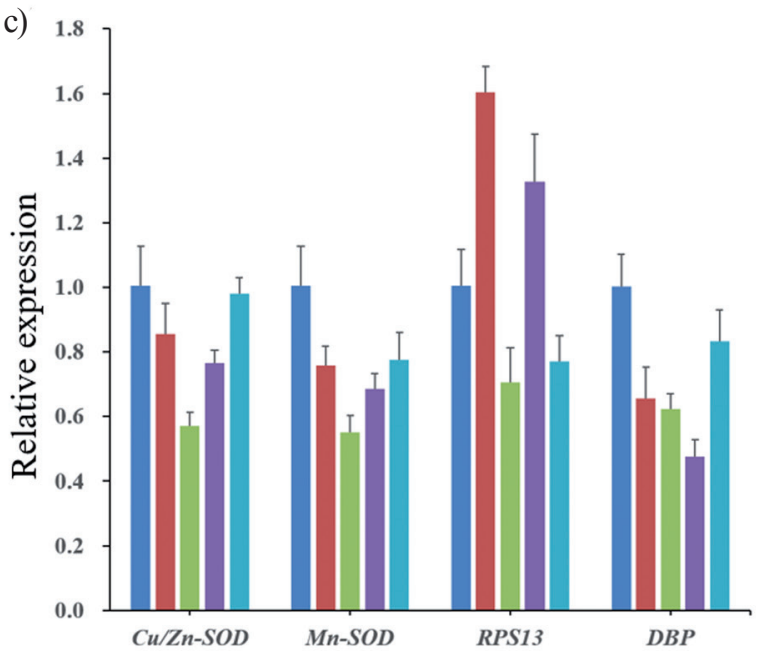

b)

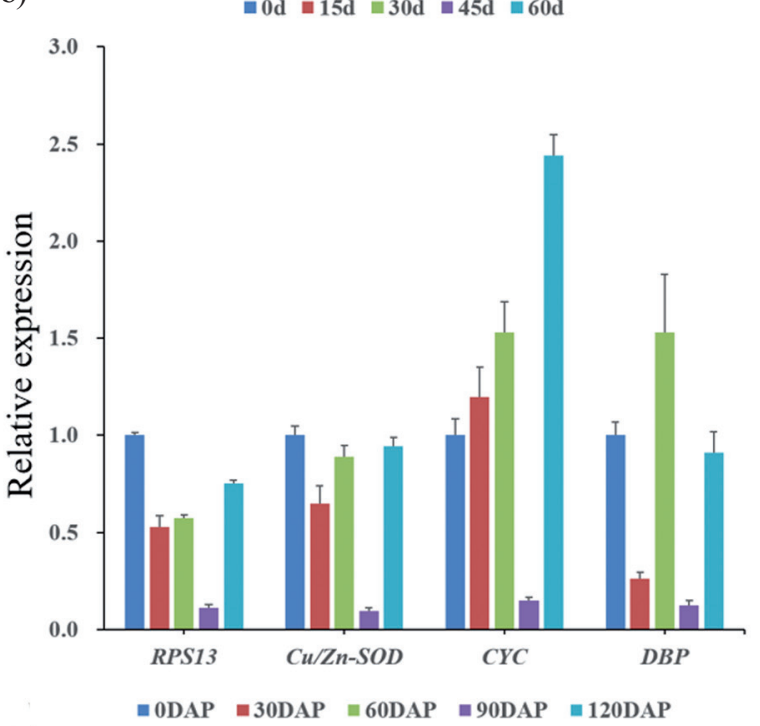

d)

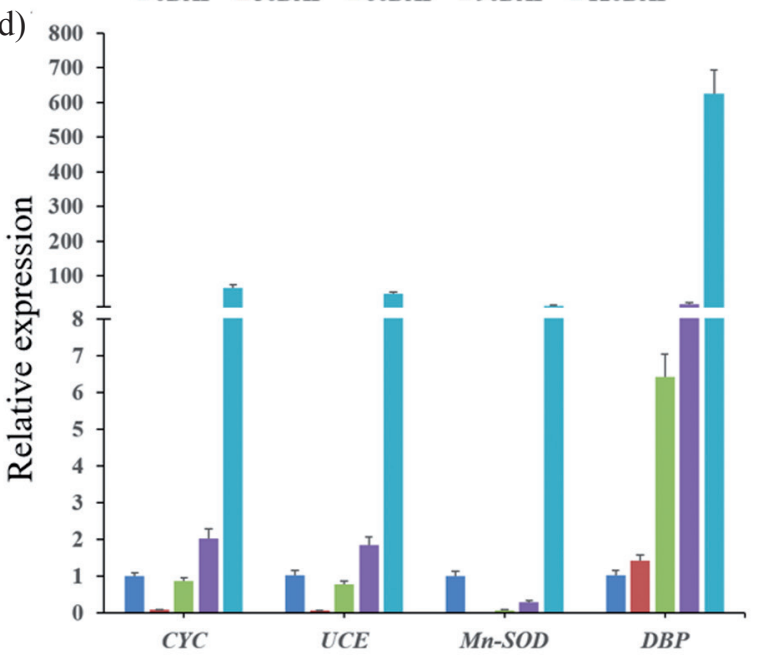

Fig. 4. Normalised expression pattern of $M s D O G 1$ using the validated reference genes under certain experimental backgrounds. These experimental series contain a) different organ tissues, b) seed stratification treatment, c) seed imbibition treatment, and d) different seed developmental stages. Mean Ct value was determined based on three technical and three biological duplicates and used in subsequent gene expression analyses. Error bar stands for standard deviation. 
the two genes having the highest expression stability, and the lowest expression stability values were both 0.176 for different organ tissues and both 0.090 for seeds at different developmental stages. $M n-S O D$ exhibited the highest expression stability (0.089) for seeds under imbibition treatment, whereas $\mathrm{Cu} / \mathrm{Zn}-\mathrm{SOD}$ exhibited the highest expression stability $(0.102)$ for seeds during stratification treatment. Finally, UCE was identified as the potential gene with the highest stability (0.157), whereas $D B P$ was identified as the potential gene with the lowest stability (1.808) in total samples.

The BestKeeper algorithm is also an Excel-based approach for identifying gene stability according to standard deviation (SD) and coefficient of variation (CV) from the quantification cycle $(\mathrm{Cq})$ values [28]. Candidate genes with the highest expression stability exhibited the lowest SD and CV [28]. In the present work, CYC $(0.50 \pm 3.06)$ was determined as the most stably expressed gene for different organ tissues, $A C T(0.31 \pm 1.40)$ for seeds under imbibition treatment, $\mathrm{Cu} / \mathrm{Zn}$-SOD $(0.12 \pm 0.64)$ for seeds during stratification treatment, RPS13 $(0.37 \pm 1.69)$ for seeds at different developmental stages, and UCE $(0.65 \pm 3.09)$ in total samples.

\section{Verification of Those Determined Reference Genes}

For verifying the suitability of the screened reference gene for normalising RT-qPCR data under diverse experiment conditions, MsDOG1 expression was investigated using the reference genes with the highest and lowest stability as internal controls (Fig. 4). For diverse organ tissues, MsDOG1 was highly expressed in root, followed by petiole, leaf, stem, and then in flower when applying the two most stable reference genes $(C Y C, U C E)$. However, a different bias was observed when applying the two least stable reference genes (RPS13, DBP) (Fig. 4a). The normalisation results of the MSDOG1 expression in seeds were identical when selecting the two stable genes (RPS13 and $\mathrm{Cu} / \mathrm{Zn}-\mathrm{SOD}$ ) as internal controls during stratification, whereas major differences were displayed when normalising target genes against reference genes with the lowest stability (CYC and $D B P$ ) (Fig. 4b). For seeds under imbibition treatment, MSDOG1 was highly expressed in each imbibed time point across the reference genes. Nonetheless, the variation patterns normalised with reference genes exhibiting the highest stability ( $\mathrm{Cu} / \mathrm{Zn}-\mathrm{SOD}, \mathrm{Mn}-\mathrm{SOD})$, and the reference genes exhibiting the lowest stability (RPS13, DBP) apparently differed (Fig. 4c). In seeds at different developmental stages, similar MsDOG1 expression tendencies were observed when using $C Y C$ and UCE (the most stable) as reference genes. The utilisation of $M n-S O D$ and $D B P$ (the least stable) as reference genes led to the obvious underestimation of $M s D O G 1$ expression at two developmental stages (60 and 90 DAP) and overestimation at four stages
(30, 60, 90, and 120 DAP), respectively (Fig. 4d). Thus, suitable reference genes must be selected to accurately normalise target gene expression.

\section{Discussion}

The gene expression analysis could result in a comprehensive understanding of gene functions. Although the accuracy and sensitivity of RT-qPCR makes it an ideal method for analysing the gene expression, a reliable and veracious outcome depends on whether a suitable reference gene is applied [6, 13]. An ideal reference gene must have unchanged expression under different conditions. Nonetheless, there may be no such an optimal reference gene [23]. For example, RPS13 displayed high stability during seed development, but ranked poorly during flower development for Sacha inchi [15]. DBP was reported to be homogeneously expressed under light quality treatment, but possessed a relatively unstable expression under low temperature treatment in strawberry [16]. Therefore, it is crucial to validate the suitable reference genes prior to RT-qPCR analysis at certain experimental conditions [31, 55]. To the best of our knowledge, the present study pioneers the systematic investigation of the choice of suitable reference genes for RT-qPCR analysis within $M$. sieboldii.

In the present work, seven potential reference gene expression stability was evaluated within $M$. sieboldii under different experimental subgroups such as 'different organ tissues,' 'seed developmental stages,' 'seed imbibition,' and 'seed stratification' treatments. The primers possessed excellent specificity because a single peak existed in the analysis of the melting curve. Additionally, RT-qPCR displayed high efficiency for all candidate reference genes (nearly 100\%). These findings suggested the suitability of our primers to analyse reference gene expression stability.

The seven potential reference gene expression stability was estimated by three computational methods (geNorm, NormFinder, and BestKeeper). The ranking order for the identified reference genes produced through various statistical algorithms displayed certain divergences. For example, according to the three algorithms in the 'different organ tissues' set, $C Y C$, $U C E$, and $C u / Z n-S O D$ were the three most stable genes, whereas $U C E$ and $C u / Z n-S O D$ altered positions in the BestKeeper analysis. In the 'seed developmental stages' set, CYC was the best reference gene according to the geNorm and NormFinder estimation, whereas it ranked $4^{\text {th }}$ in the BestKeeper estimation. For the 'seed imbibition' set, $C u / Z n-S O D, M n-S O D$, and $A C T$ were the best reference genes for geNorm, NormFinder, and BestKeeper analysis, respectively. For the "seed stratification" set, $A C T$ exhibited the highest stability according to geNorm, whereas $\mathrm{Cu} / \mathrm{Zn}$-SOD was predicted by NormFinder and BestKeeper as the optimal reference gene. Stability ranking discrepancies of these 
methods are also observed in other studies [18, 36, 56, 57], most likely due to the various statistical models and analytical procedures that they adopt.

$M n-S O D$ was the most stable reference gene for the 'seed imbibition' group; however, it did not rank high in the 'seed developmental stages', 'different organ tissues', 'total', and 'seed stratification' sets. Similarly, $M n-S O D$ might not be the appropriate reference gene in longan during somatic embryogenesis [58]. In the current study, UCE was suggested to be the optimal candidate reference gene among the tested genes under seed development, total and different organ tissues. This finding was concurrent with that reported in Plukenetia volubilis, demonstrating that UCE was the best reference gene in seed development, total and different organ tissues [15]. However, UCE was demonstrated to be one of the most variable reference genes in tung tree and Jatropha curcas [17, 59]. ACT was widely applied as reliable reference gene for RTqPCR normalization [60, 61]. This study indicated that $A C T$ was the best reference gene but only under seed imbibition and not in other conditions. In line with this, $A C T$ was reported to be the worst reference gene in pear [62] and apple [34]. DBP was considered an appropriate reference gene in strawberry in the different organ tissues, fruit developmental stages and fruit under red light treatment [16]. Nevertheless, $D B P$ performed poorly as the reference gene in the strawberry fruit's response to osmotic stress [63]. Identical to this, in this study, $D B P$ always occupied the bottom position (Table 4), indicating that it might be inappropriate for gene expression analysis in $M$. sieboldii. Overall, these results show that the reliable reference genes differ among species, tissues or experimental conditions. Therefore, the reference gene choice is extremely vital.

In our study, the CYC gene was ranked higher in different organ tissues and seeds at different developmental stages, which is similar to the findings in bamboo and Plukenetia volubilis [15, 64, 65]. The RPS13 gene, which was adopted for RT-qPCR normalisation in Petunia hybrida [33], might also act as a suitable reference gene for the investigation of M. sieboldii seed stratification. $\mathrm{Cu} / \mathrm{Zn}-\mathrm{SOD}$ was ranked within the top three best reference genes for all subset samples (Table 4). Thus, $\mathrm{Cu} / \mathrm{Zn}$-SOD was recommended for RT-qPCR normalisation in M. sieboldii. $\mathrm{Cu} / \mathrm{Zn}-\mathrm{SOD}$ was also identified as the most stable reference gene during somatic embryogenesis cultured under different temperatures in longan [58].

DOG1 negatively modulates the seed germination and flowering time $[49,66]$. Apart from the effects on plant development, DOG1 also participate in seed response to chilling [50]. To verify the appropriateness of the determined reference genes, the relative MSDOG1 gene expression was detected via reference genes exhibiting the highest and lowest stability for all subgroups with the exception of 'total' (Fig. 4).
MSDOG1 gene expression patterns exhibited high identity when normalising expression using reference genes with the highest stability. However, the normalisation results of MsDOG1 were significant different via application of the most variable genes. The reference genes played a crucial role in the normalisation of RT-qPCR data. Additionally, adopting the unsuitable reference genes can elicit inaccurate results. Hence, reliable reference genes must be selected for gene expression studies.

Gene expression analysis is essential for clarifying the molecular mechanisms underlying various biological processes [3]. The deep seed dormancy, which is a hamper for $M$. sieboldii breeding, is a crucial field of biological research. In our study, the optimal reference genes were identified in $M$. sieboldii under different experimental conditions to ensure the accurate RT-qPCR results. Among these, gene expression levels related to seed imbibition and stratification may contribute to elucidate the potential molecular mechanisms of seed dormancy breaking, which provide a guideline for optimising $M$. sieboldii growth.

\section{Conclusions}

To the best of our knowledge, the present work pioneers the systematic investigation of the choice of appropriate reference genes for the RT-qPCR within $M$. sieboldii. The $C Y C$ and UCE genes were recommended as reference genes within diverse organs as well as seeds in diverse development periods. The $\mathrm{Cu} / \mathrm{Zn}$-SOD and $M n-S O D$ genes were identified as the optimal reference genes under seed imbibition treatment, and the $\mathrm{Cu} / \mathrm{Zn}-\mathrm{SOD}$ and RPS13 genes exhibited the highest stability under seed stratification treatment. $\mathrm{Cu} / \mathrm{Zn}-\mathrm{SOD}$ was suitable for gene expression analysis in $M$. sieboldii. In contrast, $D B P$ was inappropriate for RT-qPCR normalisation in $M$. sieboldii. MsDOG1 gene expression analysis proved that the utilisation of the appropriate reference genes was critical for obtaining precise RT-qPCR results. Thus, the results from this study provide a framework for selecting suitable reference genes for the accurate RT-qPCR analysis of $M$. sieboldii.

\section{Acknowledgments}

We are grateful to anonymous reviewers for helpful comments on the manuscript. This study was supported by National Natural Science Foundation of China (31971647 and 31570621).

\section{Conflict of Interest}

The authors declare no conflict of interest. 


\section{References}

1. LU X., WANG N., LI T., HAN Y., YANG J. Effect of different soaking and accelerating germination disposals on forced germination of M. sieboldii k. koch seeds. J Northwest A \& F University (Natural Science Edition), 5, 24, 2008.

2. ZHANG X., LIU G., LI T., QI M., MEI M., LU X. Differential proteome analysis of mature and germinated seeds of Magnolia sieboldii K. Koch. Trees, 28, 859, 2014.

3. BUSTIN S.A., BENES V., NOLAN T., PFAFFL M.W. Quantitative real-time RT-PCR-a perspective. J Mol Endocrinol, 34, 597, 2005.

4. WONG M.L., MEDRANO J.F. Real-time PCR for mRNA quantitation. Biotechniques, 39, 75, 2005.

5. MAROUFI A., VAN BOCKSTAELE E., DE LOOSE M. Validation of reference genes for gene expression analysis in chicory (Cichorium intybus) using quantitative real-time PCR. BMC Mol Biol, 11, 15, 2010.

6. NICOT N., HAUSMAN J.F., HOFFMANN L., EVERS D. Housekeeping gene selection for real-time RT-PCR normalization in potato during biotic and abiotic stress. J Exp Bot, 56, 2907, 2005.

7. UDVARDI M.K., CZECHOWSKI T., SCHEIBLE W.R. Eleven golden rules of quantitative RT-PCR. Plant Cell, 20, 1736, 2008.

8. YE X., ZHANG F., TAO Y., SONG S., FANG J. Reference gene selection for quantitative real-time PCR normalization in different cherry genotypes, developmental stages and organs. Sci Hortic-Amsterdam, 181, 182, 2015.

9. VANGUILDER H.D., VRANA K.E., FREEMAN W.M. Twenty-five years of quantitative PCR for gene expression analysis. Biotechniques, 44, 619, 2008.

10. BUSTIN S.A., BENES V., GARSON J.A., HELLEMANS J., HUGGETT J., KUBISTA M., MUELLER R., NOLAN T., PFAFFL M.W., SHIPLEY G.L., VANDESOMPELE J., WITTWER C.T. The MIQE guidelines: minimum information for publication of quantitative real-time PCR experiments. Clin Chem, 55, 611, 2009.

11. GUTIERREZ L., MAURIAT M., GUÉNIN S., PELLOUX J., LEFEBVRE J.F., LOUVET R., RUSTERUCCI C., MORITZ T., GUERINEAU F., BELLINI C., VAN WUYTSWINKEL O. The lack of a systematic validation of reference genes: a serious pitfall undervalued in reverse transcription-polymerase chain reaction (RT-PCR) analysis in plants. Plant Biotechnol J, 6, 609, 2008.

12. GUÉNIN S., MAURIAT M., PELLOUX J., VAN WUYTSWINKEL O., BELLINI C., GUTIERREZ L. Normalization of qRT-PCR data: the necessity of adopting a systematic, experimental conditions-specifc, validation of references. J Exp Bot, 60, 487, 2009.

13. BUSTIN S.A. Quantification of mRNA using real-time reverse transcription PCR (RT-PCR): trends and problems. J Mol Endocrinol, 29, 23, 2002.

14. CHANDNA R., AUGUSTINE R., BISHT N.C. Evaluation of candidate reference genes for gene expression normalization in Brassica juncea using real time quantitative RT-PCR. PloS ONE, 7, e36918, 2012.

15. NIU L., TAO Y.B., CHEN M.S., FU Q., LI C., DONG Y., WANG X., HE H., XU Z.F. Selection of reliable reference genes for gene expression studies of a promising oilseed crop, Plukenetia volubilis, by real-time quantitative PCR. Int J Mol Sci, 16, 12513, 2015.

16. ZHANG Y., PENG X., LIU Y., LI Y., LUO Y., WANG X., TANG H. Evaluation of suitable reference genes for qRT-
PCR normalization in strawberry (Fragaria $\times$ ananassa) under different experimental conditions. BMC Mol Biol, 19, 8, 2018.

17. ZHANG L., HE L.L., FU Q.T., XU Z.F. Selection of reliable reference genes for gene expression studies in the biofuel plant Jatropha curcas using real-time quantitative PCR. Int J Mol Sci, 14, 24338, 2013.

18. SUDHAKAR REDDY P., SRINIVAS REDDY D., SIVASAKTHI K., BHATNAGAR-MATHUR P., VADEZ V., SHARMA K.K. Evaluation of Sorghum [Sorghum bicolor (L.)] reference genes in various tissues and under abiotic stress conditions for quantitative real-time PCR data normalization. Front Plant Sci, 7, 529, 2016.

19. LI J., HAN J., HU Y., YANG J. Selection of reference genes for quantitative real-time PCR during flower development in tree peony (Paeonia suffruticosa Andr.). Front Plant Sci, 7, 516, 2016.

20. QI S., YANG L., WEN X., HONG Y., SONG X., ZHANG M., DAI S. Reference gene selection for RT-qPCR analysis of flower development in Chrysanthemum morifolium and Chrysanthemum lavandulifolium. Front Plant Sci, 7, 287, 2016.

21. LI W., QIAN Y.Q., HAN L., LIU J.X., SUN Z.Y. Identification of suitable reference genes in buffalo grass for accurate transcript normalization under various abiotic stress conditions. Gene, 547, 55, 2014.

22. SINHA P., SAXENA R.K., SINGH V.K., KRISHNAMURTHY L., VARSHNEY R.K. Selection and validation of housekeeping genes as reference for gene expression studies in Pigeonpea (Cajanus cajan) under heat and salt stress conditions. Front Plant Sci, 6, 1071, 2015.

23. ARTICO S., NARDELI S.M., BRILHANTE O., GROSSIDE-SA M.F., ALVES-FERREIRA M. Identification and evaluation of new reference genes in Gossypium hirsutum for accurate normalization of real-time quantitative RTPCR data. BMC Plant Biol, 10, 49, 2010.

24. VANDESOMPELE J., DE PRETER K., PATTYN F., POPPE B., VAN ROY N., DE PAEPE A., SPELEMAN F. Accurate normalization of real-time quantitative RT-PCR data by geometric averaging of multiple internal control genes. Genome Biol, 3, RESEARCH0034, 2002.

25. TONG Z., GAO Z., WANG F., ZHOU J., ZHANG Z. Selection of reliable reference genes for gene expression studies in peach using real-time PCR. BMC Mol Biol, 10, 71, 2009.

26. CHEN L., ZHONG H.Y., KUANG J.F., LI J.G., LU W.J., CHEN J.Y. Validation of reference genes for RT-qPCR studies of gene expression in banana fruit under different experimental conditions. Planta, 234, 377, 2011.

27. ANDERSEN C.L., JENSEN J.L., ØRNTOFT T.F. Normalization of realtime quantitative reverse transcription-PCR data: a model-based variance estimation approach to identify genes suited for normalization, applied to bladder and colon cancer data sets. Cancer Res, 64, 5245, 2004.

28. PFAFFL M.W., TICHOPAD A., PRGOMET C., NEUVIANS T.P. Determination of stable housekeeping genes, differentially regulated target genes and sample integrity: bestKeeper-Excel-based tool using pair-wise correlations. Biotechnol Lett, 26, 509, 2004.

29. YEAP W.C., LOO J.M., WONG Y.C., KULAVEERASINGAM H. Evaluation of suitable reference genes for qRT-PCR gene expression normalization in reproductive, vegetative tissues and 
during fruit development in oil palm. Plant Cell Tiss Org, 116, 55, 2014.

30. KIM S.J., NA J.U., KIM J.S., LEE J.E., NIE H., LEE K.A., WOO S.Y., KIM S.H. Identification of valid reference genes for quantitative RT-PCR in Caragana microphylla under salt and drought stresses. Physiol Mol Biol Plants, 26, 2103, 2020.

31. WU J., ZHANG H., LIU L., LI W., WEI Y., SHI S. Validation of reference genes for RT-qPCR studies of gene expression in preharvest and postharvest longan fruits under different experimental conditions. Front Plant Sci, 7, 780, 2016.

32. WANG B., DUAN H., CHONG P., SU S., SHAN L., YI D., WANG L., LI Y. Systematic selection and validation of suitable reference genes for quantitative real-time PCR normalization studies of gene expression in Nitraria tangutorum. Sci Rep, 10, 15891, 2020.

33. MALLONA I., LISCHEWSKI S., WEISS J., HAUSE B., EGEA-CORTINES M. Validation of reference genes for quantitative real-time PCR during leaf and flower development in Petunia hybrida. BMC Plant Biol, 10, 4, 2010.

34. STORCH T.T., PEGORARO C., FINATTO T., QUECINI V., ROMBALDI C.V., GIRARDI C.L. Identification of a novel reference gene for apple transcriptional profiling under postharvest conditions. PLoS ONE, 10, e0120599, 2015.

35. ZHANG K., LI M., CAO S., SUN Y., LONG R., KANG J., YAN L., CUI H. Selection and validation of reference genes for target gene analysis with quantitative real-time PCR in the leaves and roots of Carex rigescens under abiotic stress. Ecotoxicol Environ Saf, 168, 127, 2019.

36. XU L., XU H., CAO Y., YANG P., FENG Y., TANG Y., YUAN S., MING J. Validation of reference genes for quantitative real-time PCR during bicolor tepal development in Asiatic hybrid lilies (Lilium spp.). Front Plant Sci, 8, 669, 2017.

37. PARK M., HONG S.G., PARK H., LEE B.H., LEE H. Identification of reference genes for RT-qPCR in the Antarctic moss Sanionia uncinata under abiotic stress conditions. PLoS ONE, 13, e0199356, 2018.

38. JAIN M., NIJHAWAN A., TYAGI A.K., KHURANA J.P. Validation of housekeeping genes as internal control for studying gene expression in rice by quantitative realtime PCR. Biochem Biophys Res Commun, 345, 646, 2006.

39. YANG Q., YIN J., LI G., QI L., YANG F., WANG R. Reference gene selection for qRT-PCR in Caragana korshinskii Kom. under different stress conditions. Mol Biol Rep, 41, 2325, 2014.

40. LI Z., LU H., HE Z., WANG C., WANG Y., JI X. Selection of appropriate reference genes for quantitative real-time reverse transcription PCR in Betula platyphylla under salt and osmotic stress conditions. PLoS ONE, 14, e0225926, 2019.

41. GIMENO J., EATTOCK N., VAN D.A., BLUMWALD E. Selection and validation of reference genes for gene expression analysis in switchgrass (Panicum virgatum) using quantitative real-time RT-PCR. PLoS ONE, 9, e91474, 2014.

42. HUANG L., YAN H., JIANG X., ZHANG X., ZHANG Y., HUANG X., ZHANG Y., MIAO J., XU B., FRAZIER T., ZHAO B. Evaluation of candidate reference genes for normalization of quantitative RT-PCR in switchgrass under various abiotic stress conditions. BioEnerg Res, 7, 1201, 2014.
43. MA R., XU S., ZHAO Y.C., XIA B., WANG R. Selection and validation of appropriate reference genes for quantitative real-time PCR analysis of gene expression in Lycoris aurea. Front Plant Sci, 7, 536, 2016.

44. OBRERO A., DIE J.V., ROMAN B., GOMEZ P., NADAL $S$. Selection of reference genes for gene expression studies in zucchini (Cucurbita pepo) using qPCR. J Agr Food Chem, 59, 5402, 2011.

45. YANG J., YANG X., KUANG Z., LI B., LU X., CAO X., KANG J. Selection of suitable reference genes for qRTPCR expression analysis of Codonopsis pilosula under different experimental conditions. Mol Biol Rep, 47, 4169, 2020.

46. ZHUANG H., FU Y., HE W., WANG L., WEI Y. Selection of appropriate reference genes for quantitative real-time PCR in Oxytropis ochrocephala Bunge using transcriptome datasets under abiotic stress treatments. Front Plant Sci, 6, 475, 2015.

47. LI M.Y., WANG F., JIANG Q., WANG G.L., TIAN C., XIONG A.S. Validation and comparison of reference genes for qPCR normalization of celery (apiumgraveolens) at different development stages. Front Plant Sci, 7, 313, 2016.

48. MEI M., WEI J., AI W., ZHANG L., LU X.J. Integrated RNA and miRNA sequencing analysis reveals a complex regulatory network of Magnolia sieboldii seed germination. Sci Rep, 11, 10842, 2021.

49. HUO H., WEI S., BRADFORD K.J. DELAY OF GERMINATION1 (DOG1) regulates both seed dormancy and flowering time through microRNA pathways. Proc Natl Acad Sci USA, 113, E2199, 2016.

50. MARTÍNEZ-BERDEJA A., STITZER M.C., TAYLOR M.A., OKADA M., EZCURRA E., RUNCIE D.E., SCHMITT J. Functional variants of DOGI control seed chilling responses and variation in seasonal life-history strategies in Arabidopsis thaliana. Proc Natl Acad Sci USA, 117, 2526, 2020.

51. HELLEMANS J., MORTIER G., DE P.A., SPELEMAN F., VANDESOMPELE J. qBase relative quantification framework and software for management and automated analysis of real-time quantitative PCR data. Genome Biol, 8, R19, 2007.

52. SILVEIRA E.D., ALVES-FERREIRA M., GUIMARÃES L.A., DA SILVA F.R., CARNEIRO V.T. Selection of reference genes for quantitative real-time PCR expression studies in the apomictic and sexual grass Brachiaria brizantha. BMC Plant Biol, 9, 84, 2009.

53. FERNANDEZ P., DI RIENZO J.A., MOSCHEN S., DOSIO G.A., AGUIRREZÁBAL L.A., HOPP H.E., PANIEGO N., HEINZ R.A. Comparison of predictive methods and biological validation for qPCR reference genes in sunflower leaf senescence transcript analysis. Plant Cell Rep, 30, 63, 2011.

54. DE LIMA J.C., DE COSTA F., FÜLlER T.N., RODRIGUES-CORRÊA K.C., KERBER M.R., LIMA M.S., FETT J.P., FETT-NETO A.G. Reference genes for qPCR analysis in resin-tapped adult slash pine as a tool to address the molecular basis of commercial resinosis. Front Plant Sci, 7, 849, 2016.

55. NARSAI R., IVANOVA A., WHELAN J. Defining reference genes in Oryza sativa using organ, development, biotic and abiotic transcriptome datasets. BMC Plant Biol, 10, 56, 2010.

56. DELPORTE M., LEGRAND G., HILBERT J.L., GAGNEUL D. Selection and validation of reference genes for quantitative real-time PCR analysis of gene expression in Cichorium intybus. Front Plant Sci, 6, 651, 2015. 
57. MANGEOT-PETER L., LEGAY S., HAUSMAN J.F., ESPOSITO S., GUERRIERO G. Identification of reference genes for RT-qPCR data normalization in Cannabis sativa stem tissues. Int J Mol Sci, 17, 1556, 2016.

58. LIN Y.L., LAI Z.X. Reference gene selection for qPCR analysis during somatic embryogenesis in longan tree. Plant Sci, 178, 359, 2010.

59. HAN X., LU M., CHEN Y., ZHAN Z., CUI Q., WANG $Y$. Selection of reliable reference genes for gene expression studies using real-time PCR in tung tree during seed development. PLoS ONE, 7, e43084, 2012.

60. ZHONG H.Y., CHEN J.W., LI C.Q., CHEN L., WU J.Y., CHEN J.Y., LU W.J., LI J.G. Selection of reliable reference genes for expression studies by reverse transcription quantitative real-time PCR in litchi under different experimental conditions. Plant Cell Rep, 30, 641, 2011.

61. GALLI V., DA SILVA MESSIAS R., DOS ANJOS E SILVA S.D., ROMBALDI C.V. Selection of reliable reference genes for quantitative real-time polymerase chain reaction studies in maize grains. Plant Cell Rep, 32, 1869, 2013

62. WU T., ZHANG R.P., GU C., WU J.Y., WAN H.J., ZHANG S.J., ZHANG S.L. Evaluation of candidate reference genes for real time quantitative PCR normalization in pear fruit. Afr J Agr Res, 7, 3701, 2012.

63. GALLI V., BOROWSKI J.M., PERIN E.C., DA SILVA MESSIAS R., LABONDE J., DOS SANTOS PEREIRA I., DOS ANJOS SILVA S.D., ROMBALDI C.V. Validation of reference genes for accurate normalization of gene expression for real time-quantitative PCR in strawberry fruits using diferent cultivars and osmotic stresses. Gene, 554, 205, 2015

64. FAN C., MA J., GUO Q., LI X., WANG H., LU M. Selection of reference genes for quantitative real-time PCR in bamboo (Phyllostachys edulis). PLoS ONE, 8, e56573, 2013.

65. ZHAO D., WANG X., CHEN J., HUANG Z., HUO H., JIANG C., HUANG H., ZHANG C., WEI S. Selection of reference genes for qPCR normalization in buffalobur (Solanum rostratum Dunal). Sci Rep, 9, 6948, 2019.

66. LI X.Y., CHEN T.T., LI Y., WANG Z., CAO H., CHEN F.Y., LI Y., SOPPE W.J., LI W.L., LIU Y.X. ETR1/RDO3 regulates seed dormancy by relieving the inhibitory effect of the ERF12-TPL complex on DELAY OF GERMINATION 1 expression. Plant Cell, 31, 832, 2019. 